\title{
Effectiveness of "Selection of Duta Endek Denpasar City" Program as a Cultural Legal Conservation Effort
}

\author{
I Made Wimas Candranegara, I Wayan Mirta, I Dewa Gede Putra Sedana \\ Faculty of Social and Political Science \\ University of Warmadewa \\ Denpasar, Indonesia \\ wimascandranegara3491@gmail.com
}

\begin{abstract}
One of culture entity in the city of Denpasar is the Endek cloth. There is a history of the development of Endek cloth in Bali, this cloth has been handed down from generation to ancestor of Bali, every year to year this cloth always experience rapid development. Method used is qualitative descriptive research method. The results show that that the program "Elections Duta Endek Denpasar City" is very effectively implemented every year as an effort to preserve local culture with the tip of the spear is the younger generation. The suggestion of this research is that it would be better if the Balinese people take care of and preserve the heritage of the ancestors and introduce to the broad audiences, in the sense not only to the Balinese people, because in fact the Endek cloth can also be combined with other fabrics.
\end{abstract}

\section{Keywords-culture; Endek handicraft; effectiveness}

\section{INTRODUCTION}

The city of Denpasar is one of the capital cities on the island of Bali. The city is famous for its beauty, both nature and the city, besides the solidarity of Hindu community is very thick. Culture in the city of Denpasar is very diverse.

One example of culture in the city of Denpasar is the Endek cloth. There is a history of the development of Endek cloth in Bali, this cloth has been handed down from generation to ancestor of Bali, every year to year this cloth always experience rapid development. Endek began to develop since 1985, namely during the reign of King Dalem Waturenggong in Gelgel Klungkung. Endek cloth is then developed around the area Klungkung. However, Endek began to grow rapidly after the independence period. The development of Endek fabrics in Sulang Village began in 1975 and then grew rapidly in 1985 until now. Can be seen in 1985-1995 Endek fabrics experience heyday due to the support of the government.

Effectiveness is one of the achievements that an organization wants to achieve. To obtain the theory of effectiveness researchers can use concepts in management and organizational theory especially related to the theory of effectiveness. Effectiveness cannot be equated with efficiency. Because both have different meanings, although in the various uses of the word efficiency is attached to the word effectiveness. Efficiency implies a comparison between cost and outcome, while effectiveness is directly linked to goal achievement.

Atmosoeprapto [1] States Effectiveness is doing the right thing, while efficiency is doing the right thing, or effectiveness is the extent to which we achieve goals and efficiency is how we mix all the resources carefully. Effectiveness has three levels as based on [2], among others:

\section{A. Effectiveness of Individuals}

Individual effectiveness is based on an individual's view that emphasizes the work of an employee or member of the organization.

\section{B. Group effectiveness}

The view that individuals are actually working together in groups. So group effectiveness is the sum of the contributions of all members of his group.

\section{Effectiveness of the Organization}

Meanwhile, Sharma in Tangkilisan [3] provides criteria or measures of organizational effectiveness regarding internal organizational factors and external factors of the organization, among others:

1) Organization productivity or output

2) Effectiveness of the organization in the form of its success adjust to changes within and outside the organization

3) There is no tension within the organization or constraints of conflict between parts of the organization. Meanwhile Steers in Tangkilisan [3] suggests five criteria in the measurement of organizational effectiveness are:

- Productivity;

- Adaptability or flexibility;

- Job satisfaction;

- Powering ability;

- Search for resources. 
Tangkilisan [3] says different things that organizational effectiveness can also be measured through:

- The clarity of goals to be achieved

- Clarity of achievement of goals strategy

- The process of analysis and the formulation of a solid policy

- The planning is mature

- Preparation of the right program

- Availability of facilities and infrastructure

- A system of supervision and control that is educational.

As for Handayaningrat [4] says that "Effectiveness is a measurement in the sense of achieving a predetermined goal or goal". So if the goal has been achieved, then it can be said to be effective. Still in the same book. This is reinforced by [4] that "effectiveness is the achievement of an explicit and implicit target". The same thing is also put forward by Handayaningrat [4] "Effectiveness be define as the degree to which a social system. Effectiveness must be distinguished from efficiency. Efficiency is primarily concerned with goal attainments", which means effectiveness is meant as the degree to which a social system achieves its objectives.

In addition to goal achievement, Winardi [5] explains "Effectiveness is the result of a worker compared to other production results within a certain time period". If the researcher analyzes this quote, then the effectiveness is the result obtained by a worker and compared with the time spent to produce the goods/services. Effectiveness relates to the achievement of maximum performance in the sense of achieving targets related to quality, quantity and time. So this effectiveness is more oriented to the output. While the problem of using input less is a major concern.

Tangkilisan [3] means that with the degree to which an organization realizes its objectives, all these concepts only indicate the achievement of organizational goals. While how to achieve it is not discussed. Tangkilisan [3] which says "Organizational effectiveness then is the optimal organization of emphasis upon achieving object solving competence and human energy utilization" or in other words organizational effectiveness is the balance or approach optimally on achievement goals, abilities and utilization of human labor. Amirullah [6] effectiveness shows the ability of a company in achieving the target that has been specified appropriately. The achievement of predetermined targets and the applicable standards and standards reflecting a company has taken into consideration its operational effectiveness.

According to Gibson [2] concepts of effectiveness consist of two approaches: Goal approach and system approach. The two approaches are: The goal approach to determining and evaluating effectiveness is based on the idea that the organization is created as a means to an end.

Gibson [2] provide restrictions in the criteria of organizational effectiveness through systems theory approach, among others: a) Production: Production is the ability of the organization to produce the quantity and quality of output in accordance with environmental demand.

b) Efficiency: The concept of efficiency is defined as the ratio of (ratio) between output and input. Measures of efficiency should be expressed in comparison between profit and cost or with time or with output.

c) Satisfaction: Satisfaction indicates to what extent the organization meets the needs of its employees and users.

d) Adaptation: Adaptability is how far an organization can respond to external and internal changes.

e) Development: Organizations must invest in the organization itself to expand its ability to live on in the long term.

f) Sustainability: Organizations must be able to live for a long time.

Based on several theories put forward by the experts above, the researcher uses Emerson's theory in Handayaningrat [4] that "Effectiveness is a measurement in the sense of achieving a predetermined goal or goal". So if the goal has been achieved, then it can be said to be effective.

Based on the fact, this study is made to identify and describe the effectiveness of election program of Endek in Denpasar as an effort to preserve local culture.

\section{Method}

The location of the research is related to the effectiveness of the program "Selection of Endek Ambassadors of Denpasar" as an effort to preserve local culture carried out in the Denpasar City Environment, especially in the Denpasar Industry and Trade Agency and the Regional National Crafts Council (Dekranasda) Denpasar. Researchers used descriptive qualitative research methods. Research with qualitative method refers to activities to gain knowledge, information about subject and social background of research. To present the data obtained, the researchers then pour in the form of explanations or in other words using descriptive method. This method tries to give description, description about facts of phenomenon that happened in research subject. In this case the researchers used this method to find out how much the effectiveness of the Denpasar City Government program related to the activities of "Selection of Duta Endek Denpasar City" as an effort to preserve local culture. In this research, the key person who became informant is Denpasar City Government especially employees at Denpasar Industry and Trade Agency, the Chairman of the National Council of Local Handicraft (Dekranasda) Denpasar, the organizer of the program "Elections Duta Endek Denpasar City" and finalist Duta Endek Kota Denpasar.

\section{RESUlT AND DisCUSSION}

Indonesia is one country that has a wealth of cultural heritage is very diverse, both in the form of ideas/ideas, community activities, as well as in the form of work. In fact there are already some Indonesian cultural heritage that has been recognized by the United Nations Educational, Scientific, 
and Cultural Organization (UNESCO) as a world cultural heritage. Indonesian culture that has been recognized by UNESCO as world cultural heritage, among others: subak, wayang kulit, keris, and batik. In addition, Indonesia still has many other cultural heritages that need to be preserved and developed.

Bali is one of the islands in Indonesia that holds a wide range of cultural heritage that is the tourist attraction to visit Bali, in addition to the beauty of its natural panorama. Bali has a diversity of cultures spread throughout the island of Bali, both in the form of ideas/ideas, community activities and in the form of human works. This culture is a taksu of Balinese society that must be preserved and developed in the midst of a global cultural rush, as Bali is one of the world's tourist destinations that are vulnerable to global cultural influences.

Endek woven fabric is one of the cultural heritage of Bali which is the result of the work or craft of tie weaving which has diverse characteristics on the motive. Endek woven fabric had experienced its heyday in the past, but over the course of time and the influx of foreign cultural influences to Bali, this tie wears down.

The city of Denpasar as the capital of the province of Bali is currently starting to intensively promote the Endek woven fabric. Denpasar City Government through the Department of Industry and Trade (Disperindag) together with the National Regional Handicraft Board (Dekranasda) Denpasar has a selection program of Duta Endek to promote Endek woven cloth to all levels of society, including the young generation. In addition to the selection of Endek ambassadors, the Denpasar City Government also organizes weaving training for Endek city craftsmen of Denpasar, Endek woven fabric design competition, and Endek fashion show in an event titled The Exotic of Wastra. These programs are one of the efforts to realize the vision of Denpasar city, namely "Denpasar is creative with cultural insight in balance to harmony".

Endek woven fabric has enormous potential to be further developed as one of the excellent products of Denpasar city. Along with the promotion of Endek woven fabric made by the Government of Denpasar, the use of Endek woven fabric today is not only limited to religious ceremonies, but has been used in various occasions. Such as employee uniforms, school uniforms, and as a daily dress. Innovation Endek woven fabric products into various types of clothing and handicrafts made from Endek is one effort in the preservation and development of woven fabric Endek.

Based on data from the Department of Industry and Trade (Disperindag) Denpasar, there are still some groups of Endek woven artisans who do not have a special place to display and market the craft. The craftsmen are only displaying the craft at home, so less known to the public. So for that required a facility of Endek Woven Fabrics Gallery to display and market the results of woven fabric Endek in Denpasar.

The Endek woven fabric gallery that is designed is not only limited as a place to display Endek woven fabric only, but also there are various facilities that can support the existence of the gallery. One of them is a facility for artists of Endek woven fabric and fashion designers to hold a fashion show/fashion show. This gallery not only targeting the local community, but also targeting domestic tourists and foreign tourists who visit Bali, especially Denpasar. So hopefully Endek woven fabric is not only known by local people, but also known by the wider community including the international world.

Endek woven fabric is one of Indonesian traditional fabric that uses non-machine loom (ATBM). Indonesian traditional woven fabrics can be grouped into four major groups namely batik cloth, ikat, songket weave, and embroidered art. Bali is one of the areas in Indonesia that has a diversity of traditional woven fabrics. Bali Endek woven fabric has a meaning, historical value used for ceremonial purposes, whether to be worn by individuals who will do or will be treated in accordance with the customs of Bali and as a complement to the ceremony. Bali's Endek woven fabric is a capitalist fabric that is used as a mode in everyday life that can be used as decoration, personal collection, and commodity goods that can be traded and leased.

Endek woven fabric is one of the binding techniques that developed especially in Bali. Woven fabric Endek is a traditional Balinese cloth with a pattern of tied food. The beauty of the variety of ornaments in the form of flora and fauna and the motifs taken from Balinese mythology and wayang. It is the diversity of these motifs that characterize the Endek woven fabric. The process of binding to the Endek woven fabric is only done on the feed yarn before dipping into the dye. This is what distinguishes it with double/double connective technique. In a double binding technique, the binding process is carried out on the feed yarn and the warp yarn. Examples of woven fabrics that use double binding techniques are woven geringsing fabric made in Tenganan Village, Karangasem Regency.

Similar to other regions in Indonesia, Bali in particular Denpasar is very rich with traditional culture, including woven fabric. The traditional weaving fabric that develops in Denpasar is woven Endek fabric. According to the Head of Industry and Trade Agency (Disperindag) Denpasar City I Wayan Gatra in tabloid Figure 786 dated 3 - March 9, 2014, Endek woven cloth at first worn only by the parents and the nobility. However, in its development Endek woven fabric began widely used by the people of Bali and become the most important cultural identity. Endek woven fabric even had time to enjoy the heyday around 1980's.

However, along with the development of the era and the influx of foreign cultural influences to Bali resulted in woven fabric Endek experiencing downturn. This is exacerbated by the economic crisis in 1997 and the bomb incidents in 2002 and 2005 (Association of City Government of Indonesia, 2014). Some of the things that resulted in this Endek woven fabric include: Endek woven cloth is considered exclusive only for certain occasions, Endek woven fabric has a fairly expensive price, Endek woven fabric has not been able to penetrate the national market, and Endek woven fabric has not been able to compete because the Endek woven fabric has not been developed into finished products such as clothes and handicrafts (Association of City Government of Indonesia, 2014). 
The decline of Endek woven fabric that occurred after the economic crisis and Bali bombing tragedy became a major challenge for Denpasar to be able to rise to exploit the potential of Endek woven fabric. To start reviving the Endek woven fabric from its downturn, Endek woven fabric began to be worn as a uniform of employees, but still limited to the city government only. In line with the development of the use of traditional cloth in the homeland as a daily clothing, not only clothes at special times, Endek woven cloth was considered worthy of everyday clothes, especially in Denpasar (Association of Indonesian Municipalities, 2014).

Denpasar City Government held the election of "Duta Endek Denpasar" in an effort to preserve and proudly use Endek cloth as a lifestyle. "The selection of Duta Endek Denpasar' has been conducted to target the young people of Denpasar.

This activity has been carried out every year, which is choosing dozens of Endek ambassador finalists by involving three judges who are competent in their field with the theme "Endek is True quality". Selection of Endek ambassadors is done through written test and interview test which every year is followed by hundreds of participants from school to student. This activity as an effort of Denpasar City Government in socializing domestic production with slogan "Endek Kita Punya, Kita Pakai, Kita Proga".

Besides it fosters a sense of love and pride among adolescents to Endek, and provide opportunities for younger generation to be more familiar with Endek through Duta Endek Denpasar City. The event will establish "Duta Endek Putra and Putri" to win the first, second and third prize, and attend the debriefing from the Chairman of Dekranasda Denpasar, Ny. Ida Ayu Selly Dharmawijaya Mantra. Activities will also conduct a visit (visiting trip) to the Endek craftsmen in Denpasar City.

In addition to this activity, the Denpasar city government has implemented several activities to socialize Endek among the younger generation has been done together Chairman Dekranasda Denpasar City targeting schools. In addition, the activities of previous years of Endek's ambassadors also involve in the fashion competition at the national level who won the first prize, as well as conducting various Endek socialization activities at the Festival event in Denpasar City. It is expected that the winners of Endek ambassadors will be able to provide the best for the progress and improvement of local product innovation in Denpasar City through activities targeting among young people, "he said.

Based on interviews with the Head of Trade and Industry Office of Denpasar, Mr. Wayan Gatra said: "Endek is not the fashion" Old Fashion ", but it can also be applied to everyday clothes that are trendy and typical of young people. Hopefully will make clothes Endek increasingly known and loved by the community, especially the younger generation in Denpasar, "he said. This proves that in Denpasar City so far the Endek motive used by young generation varies depending on how the community wants, the model is also diverse.

Then based on an interview with the Chairman of the National Regional Crafts Council (Dekranasda) Denpasar, mistress I.A. Selly Mantra, said that so far the implementation of the program "Elections Duta Endek Denpasar City" has been running very well even if viewed from the effectiveness, activities fully supported by the Government of Denpasar City can be regarded as a program that is able to preserve the local culture itself is the Endek is the legacy of our ancestors. He also added that currently almost all the young generation and the older generation are very fond of Endek cloth has even started to be used as the identity of schools in the city of Denpasar and companies and government agencies in the city of Denpasar.

Based on the results of interviews with Champion 1 Duta Endek Denpasar City 2014, I Gusti Ayu Aura Gizella, S.Tr.Ds, event selection of Endek ambassador City of Denpasar is very effective serve as a place of preservation of local culture, especially for the young generation today in the city of Denpasar already start rolling around using Endek as their main outfit in every official activities as well as wedding reception events even every school has their own distinctive Endek clothing. Young generation in the city of Denpasar even acknowledged that the use of Endek clothing which is one of the ancestral heritage culture is a pride for the younger generation even today the existing Endek fabric motives vary and look more modern.

Based on the theory of Gibson effectiveness in Tangkilisan [3] said that the effectiveness of the program can be measured through several indicators including:

\section{A. The Clarity of Goals to be Achieved}

Associated with the program of election of the Endek ambassador of Denpasar is clear the implementation of the program objectives is very clear as a means and efforts to preserve local culture and attract young people in the city of Denpasar to love the ancestral cultural heritage that is the Endek fabric itself.

\section{B. Clarity Strategy Achievement of Goals}

Based on the results of the above interviews that it is clear can be said that the selection program of the Endek ambassador of Denpasar can be achieved by targeting strategies to the young generation in Denpasar City so that the goal of this program is able to cultivate the love of the younger generation of local cultural heritage in particular the use of Endek fabrics can be well realized.

\section{The Process of Analysis and the Formulation of a Solid Policy}

This indicator explains that in determining the implementation of the program of election of Endek ambassador of Denpasar City has been planned very mature and directed so that the output of the program can be realized well

\section{Availability of Facilities and Infrastructure}

This indicator explains that the facilities and infrastructure supporting the election program of the Endek city of Denpasar has been very adequate so that this activity can continue to be implemented every year with the target of the young generation 
as the spearhead related how the cultural heritage of the city of Denpasar that Endek cloth itself can be preserved so that in the future every the good old generation and young people want to use Endek clothes as their everyday identity.

Based on the results of the above interviews researchers can conclude that the program "selection of the Endek ambassador of Denpasar" is very effectively implemented every year as an effort to preserve local culture with the tip of the spear is the younger generation.

\section{CONCLUSION}

By the holding of the election program of Denpasar City Endek Ambassador by the Denpasar City Government at any time can be expected to run effectively so that preservation of Endek cloth as a local culture can be maintained even until our children and grandchildren later. There will be savings of Balinese people to keep and preserve the heritage of the ancestors and introduce a wide audience, in the sense not only for the Balinese people, because in fact Endek cloth can also be combined with other fabrics, such as songket originating from Minangkabau. Songket cloth is a cloth that is the color of gold or silver threads. Giving gold or silver thread can be done on the fabric Endek. Generally used as decorative edge cloth. This cloth was later known as the songket Endek fabric. That is just a small example, and even this Endek fabric brought to the international realm, because the uniqueness of the motive that cannot be found in any area. Our ancestors have given a very precious inheritance, and who will surely know very much if you can use it. For that we must preserve and preserve the heritage of our forefathers and ancestors.

\section{ACKNOWLEDGEMENT}

The author would like to thank all the parties who have helped and contributed in the writing of this article, both those who contribute in the form of funding and critical ideas. Hopefully this paper can be useful theoretically and practically for the addition and development of knowledge, especially in the field of legal science.

\section{REFERENCES}

[1] K. Atmosoeprapto, Menuju SDM Berdaya - dengan Kepemimpinan Efektif dan Manajemen Efisien. Jakarta: PT. Elex Media Komputindo, 2002.

[2] Gibson., Ivancevich., perilaku, struktur, proses. Jakarta: Binarupa Aksara, 1997.

[3] H. N. S. Tangkilisan, Manajemen Publik. Jakarta: Gramedia Widia Sarana Indonesia, 2005.

[4] S. Handayaningrat, Pengantar Ilmu Administrasi dan Manajemen. Jakarta: PT. Gunung Agung, 1996.

[5] Winardi, Manajemen Perilaku Organisasi. Bandung: Citra Aditya Bakti, 1992.

[6] Amirullah., Pengantar Manajemen. Yogyakarta: Graha Ilmu, 2002. 